\title{
Trail use and perception of a diverse mountain farming landscape by hikers in the protected area Allgäuer Hochalpen in the German Alps
}

\author{
Gerd Lupp, Markus Feuerstein, Linda Heuchele \& Werner Konold
}

Keywords: Allgäuer Hochalpen, landscape perception, trail use, interviews, internet picture assessment

\section{Abstract}

Profile

This paper assesses the use and appreciation of an Alpine mountain farming landscape with their necessary management and infrastructure in the protected area Allgäuer Hochalpen. We used a method mix to analyse official and informal trail use, combining aerial photos, pictures posted on the internet, interviews with farmers and hikers as well as observations. To assess the appreciation of different landscape elements, photos posted on the internet and their description were evaluated and interviews conducted with hikers. Only about half of the interviewees are bound for longer hikes, most of them return to the gondola after hiking for one hour. Informal trails in the study area were only used by less than $0.5 \%$ mainly to reach a mountain top or to hike around the entire lake. It could be shown that panoramic views, the lake and meadows that depending on traditional mountain farming are best liked by the interviewed hikers, who perceive it as a natural landscape. They disliked traces of the necessary infrastructure and landscape management. Since informal trail use and lack of knowledge about the protection status is not an issue in the study area, the focus should be shifted more towards raising awareness and communicating the importance of mountain farming and its contribution to biodiversity and scenic attractiveness.

\section{Introduction}

Biodiversity at the level of species, biocoenoses and landscapes is a key element and the basis for tourism; it shapes the identity of outdoor recreation sites and is one of the most important factors when choosing a destination (Pröbstl 2010). Attractive scenery, the opportunity to experience nature, and authenticity are key factors in the choice of destination in Europe and crucial for regions where nature-based tourism is an important economic factor (Großmann 2007; Tyrväinen et al. 2014). Most European landscapes are the result of a complex interaction between ecosystems and humans over many centuries (Antrop 2004). Within the Alpine arc, this complex interaction of mountain farming and nature has often led to high biodiversity and outstanding scenic beauty (Bätzing 2002). Though extensively managed farming landscapes are considered very attractive by the public (Lindemann-Matthies et al. 2010), scenic attractiveness and rich biodiversity do not correlate closely in all cases (e.g. Gobster et al. 2007; Qiu et al. 2013).

Alpine mountain farming landscapes are endangered by land-use changes like intensification or abandonment (Konold 1996; Kampmann et al. 2008; Zimmermann et al. 2010) and depend on regular extensive farming practices. They are a prime habitat for species sensitive to disturbance. Recreation activities can have a direct negative impact on biodiversity, such as disturbance of wildlife or trampling of vegetation (Liddle 1997). Studies indicate that impacts like erosion, fragmentation of habitats, disturbance of wildlife and trampling are connected with informal trails and their use (Rochefort \& Gibbons 1993; Liddle 1997; Rochefort \& Swinney 2000), though few studies address the assessment of their use. For nature conservation, site and visitor management, it is important to gain information on how sensitive Alpine mountain farming landscapes are used and appreciated by tourists. Using the protected area Allgäuer Hochalpen in the German Alps as our study area, we assess the use of the trails by aerial photographs, photos taken in the study area and posted on the internet, our own observation and interviews. In a second step, we analyse the perception of landscapes and mountain farming, which is inseparably connected with biodiversity and with the landscape's overall appearance and attractiveness. We identify those elements of landscapes and biodiversity that are considered very attractive by the recreationists and how they perceive and appreciate the mountain farming activities and related infrastructure to maintain high biodiversity and nature conservation values. To this end we use the photos posted on the internet as well as on-site interviews with hikers.

The presented study also intends to determine information and management priorities for the Natura 2000 site manager and institutions responsible for the area, such as the German Alpine Club in charge of trail maintenance, but also the political and administrative authorities (e.g. the Bavarian Departments for Food, Agriculture and Forestry at district level), which are responsible for tourism, nature conservation and agro- 


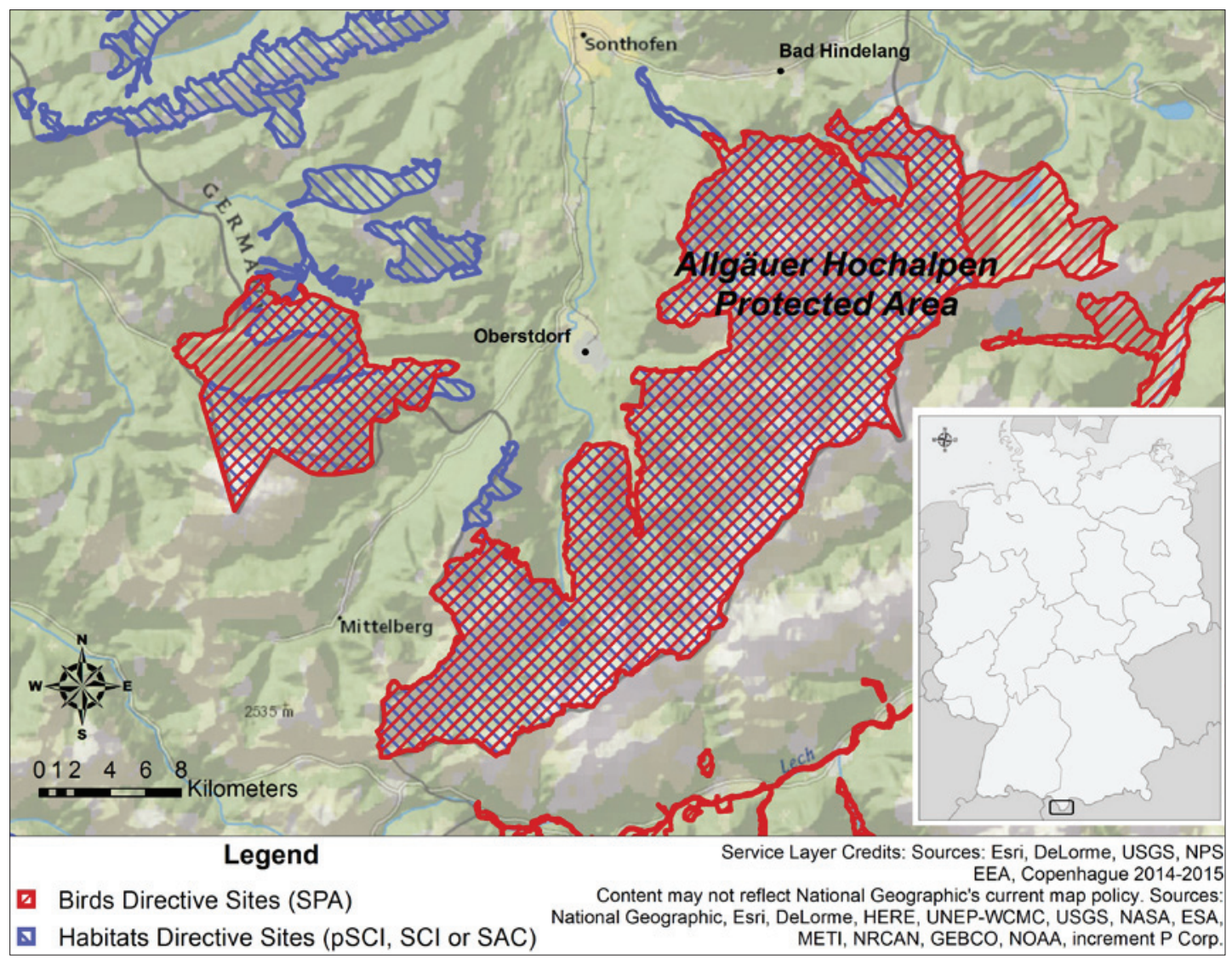

Figure 1 - Study area Allgäuer Hochalpen in the southernmost part of Germany

environmental programmes. As the relevant authorities lack the time to deal with preventive nature conservation measures, communications and local presence, the Federal Free State of Bavaria has implemented site managers for a number of Natura 2000 sites, including the Allgäuer Hochalpen (Krauss \& Schlapp 2013). The programme is co-funded by the ESF. Core tasks for these Natura 2000 site managers are communication with stakeholders and the public about nature conservation issues, conflict resolution and acting as an interface between different stakeholders.

\section{The study area}

The protected area Allgäuer Hochalpen is situated in the southernmost part of Germany in the Bavarian district of Oberallgäu. The protected area covers $207 \mathrm{~km}^{2}$ and stretches over the territory of the communities of Bad Hindelang, Sonthofen and Oberstdorf (Figure 1). The area became protected by law in 1991 and was declared a Natura 2000 site in 2002. It is considered one of the most valuable nature conservation areas within the Alpine arc (WWF 2004). The study area selected within the protected area is located southeast of Nebelhorn peak. It stretches from the summit of Kleiner Seekopf (2096 m) down to the Oytal at 1450 metres. Within the surveyed study area, almost all typical elements of the protected area and also of the northern Alpine arc can be found: tor- rents, two canyons, a lake, rock-cliffs, alpine meadows resulting from extensive cattle grazing, shrub land and forests. Within the selected area, several traces of the infrastructure necessary for mountain farming can be found, such as farming huts or water wells and drinking tanks for cattle. The study area is within reach of a cable car and a popular Alpine hut of the German Alpine Association (Edmund-Probst-Haus), which also offers accommodation. A number of marked hiking tracks as well as several informal trails provide access to the study area. Summer tourism is the most important sector for the communities in the region. The importance of tourism is indicated by 4.5 to 5 million overnight stays per year (more in summer than in winter), or an average of 101 overnight stays per inhabitant. Up to $80 \%$ of employment in the adjacent villages is thought to be related to tourism (Heuchele et al. 2014).

\section{Material and methods}

A method mix was applied to get a broader and better understanding (Cresswell 2003). First, marked and informal trails were assessed to serve as the basis for systematic observation and for designing the interviews. In a second step, photographs from the study area and their descriptions were collected from the internet. The importance of and positive connotation of different landscape elements and biodiversity were as- 


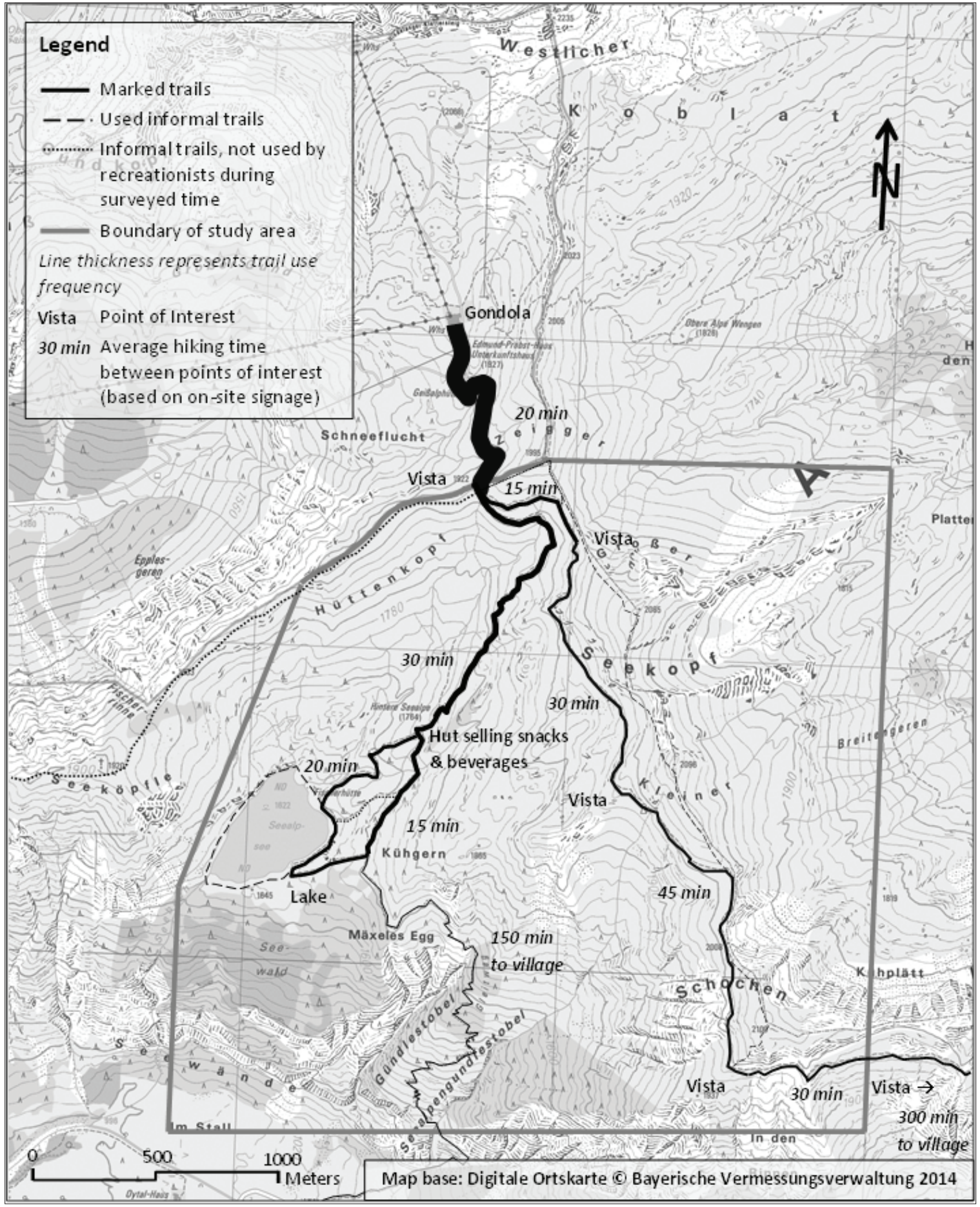

Figure 2 - Trail use and informal trails in the study area, 249 interviewees. Map design: Feuerstein, Lupp

sessed this way as well as picking up indications on which trails were used when the pictures were taken. Finally, we carried out interviews with hikers and our own observations to gain more in-depth information on trail uses, landscape perception and the importance of mountain farming for the study area. The combination of photo assessment and interviews helps to reduce the disadvantages of either approach, e. g. misinterpretation of photo contents, especially when no description is given. In a personal interview situation, social interactions between the interviewee and the in- terviewer occur. Answers might differ from actual behaviour or preference (Bortz \& Döring 2003) because of implicit social desirability, e.g. actual informal trail use in a nature conservation area versus a statement of not doing so.

\section{Trail analyses and informal trails}

All marked and informal trails in the area were mapped and user frequencies were assessed. Both officially marked and informal trails were considered for the study. We tried to map the trail network by us- 
ing aerial photos according to the method of Denecke (1969). It turned out that assessing photos and maps alone was not sufficient to map them, nor was it possible to assess trail frequentation. There was no way to detect accurately whether marks on the aerial pictures were actual trails used by recreationists or paths trampled by cattle. Cattle prefer to move and graze horizotally along the mountain slopes and form characteristic terraces. If many cattle graze in an area, the sward will erode and cannot be distinguished from informal trails. Therefore we carried out our own on-site investigations and expert interviews (Garz \& Kreimer 1991). Experts selected for interviews relating to trails were the landlord of the Alpine hut, two farmers operating in the study area and the site manager. While informal trails could be detected, the experts were unable even to give a rough estimate of the frequency of use for both the formal and informal trails. Trail use was therefore assessed in interviews with recreationists (see below). We also observed the study area during the interviews to detect whether an informal trail was actually being used in the survey period. If it could be proven that an informal trail had been used during the study period, it was indicated on the map (Figure 2).

\section{Web 2.0 photo analysis}

Web 2.0 applications allow people to share their movements by posting (geotagged) photos or routes on the internet (Orsi \& Geneletti 2013). To assess the importance and the positive or negative connotation of landscape elements in the study area as well as trails used to take these pictures, we collected photos from the internet using the Google search engine and carried out a content analysis (Macnamara 2005). We performed the search for photos using keywords. Search terms were point elements, such as the name of the two huts, the name of the lake or surrounding peaks as well as line elements, e.g. names of torrents, canyons or the name of the hiking trail. To get a specification, the geographical term Allgäuer Hochalpen was always added to the respective search terms. Two groups were formed: private postings, e.g. hiking forums, and commercial websites. Only private posts with a minimum of ten pictures were considered. Sceneries and landscape elements were evaluated according to how important they were for promoting the attractiveness of the study area. Posts on commercial websites were selected if they contained at least three pictures. Pictures were only analysed if they correctly presented the study area or parts of it. Categories were formed to analyse the content of the picture: 1 . By using the name or title of the picture, 2 . If the description was incomplete or missing, and if it was quite similar to a previous one with a description, the previous one was used. 3. If no description was attached, the dominating element in the picture was assessed and considered positive, if this was not applicable, the element taking up the most space in the photograph was used to categorize the picture.
Interviews and observation with outdoor recreationists

Recreationists were interviewed about their landscape preferences in the High Alps of the Allgäu. The survey was conducted during the early summer of 2013. A questionnaire with a quantitative approach (Atteslander 2003) was developed dealing with outdoor recreation activities; a map to draw in the trails was used, and questions about awareness of being in a protected area, appreciation of different landscape elements in the study area, and finally, some demographic data were included.

Standardized interviews seemed the most efficient way of capturing a good cross-section of summer recreationists in the study area. We chose a random selection approach (Kromrey 2009) and developed an interview routine. A period in July was chosen for the interviews as a peak season for hiking. Interviews and observations were carried out at the Zeigersattel (a mountain pass at $1923 \mathrm{~m}$ a.s.l.), a hotspot for visitors about 20 minutes' walk away from the cable car, which forms a natural gateway to the study area. A rest area with benches is provided with a panoramic view of almost the entire study area. Close to Zeigersattel a number of official and informal trails fan out.

The interview design can be found in Table 1. 275 people were asked to participate in the survey, of whom 25 rejected such participation, and 250 participated (around 90\% response rate), with one of the questionnaires only partially completed. During the interviews the study area was observed for persons using informal trails. Results were analysed using Microsoft Excel software. IBM-SPSS statistics 22 was used to run the Chi square tests.

For statistical analysis of the data, pairwise Chi square tests were carried out to detect differences between gender, previous visits, visitors coming from an urbanized or rural area, as well as originating from the Alpine arc or not. Two groups were formed for age - younger ones (below the age of 40 ) and older ones $(40+)$ as well as for formal education levels: lower formal education (no formal education up to job vocational training) and higher education (master craftsmanship diploma, university degree). These distinction lines reflect post-modern sociological theories claiming socialization leads to similarities in behavioural patterns, shared values, tastes and norms (e. g. Schulze 1997). According to Schulze (1997), one significant attribute to distinguish groups is the level of education. In this concept the line is drawn between lower formal education up to the formal job training degree and the master craftsmanship diploma or university degrees. Schulze (1997) claims that people tend to revise their behaviour patterns, values and tastes between the ages of 40 and 45. Therefore we chose to test possible differences between younger and older interviewees.

The null hypothesis was that no correlation exists between the two different groups. The significance 
Table 1 - Interview design and interview days, with weather conditions, temperatures and precipitation taken from Meteomedia, which operates a weather station on the Nebelhorn summit, approx. $2 \mathrm{~km}$ north and $300 \mathrm{~m}$ above the interview place, cloud cover as defined according to our own observations.

\begin{tabular}{|l|r|l|r|r|r|r|r|r|r|}
\hline Interview day & Start & Break & End & $\begin{array}{r}\text { Interview } \\
\text { sheets }\end{array}$ & $\left.\mathbf{T}_{\min }{ }^{\circ} \mathbf{C}\right]$ & $\mathbf{T}_{\text {max }}\left[{ }^{\circ} \mathbf{C}\right]$ & $\begin{array}{r}\text { Weather } \\
\text { morning }\end{array}$ & $\begin{array}{c}\text { Weather } \\
\text { noon }\end{array}$ & $\begin{array}{c}\text { Rainfall } \\
\text { amount [mm] }\end{array}$ \\
\hline $\begin{array}{l}\text { Monday } \\
\text { 1 July 2013 }\end{array}$ & $9: 00$ & $14: 00-14: 30$ & $17: 00$ & $1-33$ & 8.7 & 12.7 & Clear & $\begin{array}{l}\text { Cumulus } \\
\text { cloud }\end{array}$ & 0.9 \\
\hline $\begin{array}{l}\text { Tuesday } \\
\text { 2 July 2013 }\end{array}$ & $9: 00$ & $12: 50-13: 20$ & $16: 30$ & $34-81$ & 10.2 & 13.9 & Clear & Cloudy & 35.6 \\
\hline $\begin{array}{l}\text { Wednesday } \\
\text { 3 July 2013 }\end{array}$ & $9: 00$ & & $12: 20$ & $82-98$ & 8.7 & 10.9 & $\begin{array}{l}\text { Overcast } \\
\text { sky }\end{array}$ & Rainy & 14.7 \\
\hline $\begin{array}{l}\text { Sunday } \\
\text { 28 July 2013 }\end{array}$ & $8: 00$ & $13: 00-13: 30$ & $16: 00$ & $99-163$ & 17.2 & 23.4 & Cloudy & Cloudy & 0.0 \\
\hline $\begin{array}{l}\text { Tuesday } \\
\text { 30 July 2013 }\end{array}$ & $12: 20$ & $14: 00-14: 40$ & $17: 30$ & $164-205$ & 7.2 & 9.6 & Cloudy & $\begin{array}{l}\text { Low } \\
\text { cloud }\end{array}$ \\
\hline $\begin{array}{l}\text { Wednesday } \\
\text { 31 July 2013 }\end{array}$ & $10: 15$ & & $15: 00$ & $206-250$ & 11.2 & 15.0 & Cloudy & Cloudy & 0.2 \\
\hline
\end{tabular}

level was set at $p=0.05$. If $p=$ probability $<0.05$, this null hypothesis is rejected.

\section{Results}

Trail analysis and trail use

Interviewees were asked to name and mark the places within the study area which they had already passed or intended to visit. According to the interviews, $41.2 \%$ of all interviewees had just used the trail from the cable car to the rest area and returned without any further use of the trails in the study area, and the vast majority of the people going further would only do so for another 30 to 60 minutes. Main reasons for carrying on are gaining access to the lake, reaching a viewing point other than that from the Zeigersattel or visiting the hut, where a small selection of snacks and beverages are available for guests. Only about 4\% of the interviewees used informal trails. No other individuals were observed on informal trails during the survey period. The main reasons given for using the informal trails were climbing to the top of the nearby peaks (Schochen and Seekopf) and enjoying a $360^{\circ}$ panoramic view or hiking around the entire lake (see Figure 2).

Internet picture analysis

303 different pictures on the internet could be assessed. 93 of them could not be assigned to any category. They either showed objects outside the study area or the study area during the winter months, which were not the subject of this study. The remaining 207 photographs could be allocated to one of the categories. 60 showed trails, 37 peaks, 30 lake scenes, 19 total panoramic views, 10 huts, 10 plants, 8 valleys, 5 people, 5 torrents and 23 other motifs. Only three photos were described with attributes directly related to Alpine farming, two pictures with a grazing animal, and three showing (Alpine) meadows in more detail. None of the pictures were taken from the informal trails.
Interview results

Almost all interviewees were from Germany, only two from the Netherlands and Croatia, and one from New Zealand, none from neighbouring countries. This is surprising, since the study area borders directly onto Austria and would be within easy reach for hikers starting out in Austria.

More than half of the interviewees had a high educational background with a university degree or a university entrance diploma, while the German average would only be $27.3 \%$ (destatis $2013 \mathrm{a}$ ). $3.2 \%$ of the interviewees were younger than 18 years, $26.5 \%$ were within the age group $18-39$ years. $42.6 \%$ of the interviewees were 40-59 years of age, $27.7 \%$ were over 60 . Compared to the average population, the 40 to 59 age group is extremely overrepresented. Only $31 \%$ of the German population would be between 40 and 60 years of age (destatis 2013b). $36.0 \%$ visited the area for the first time, $47.2 \%$ had been there $2-9$ times and $16.8 \%$ had been in the study area more than ten times.

$69.2 \%$ considered themselves to be hikers, $22.4 \%$ were taking a walk, $7.2 \%$ were on a longer hiking trip with at least one overnight stay in the mountains (hut, bivouac) and $1.2 \%$ were on a climbing tour. $80 \%$ of the interviewees were aware that they were in a protected area, for $17.2 \%$ the protected area was the main reason for visiting the area.

A number of reasons were given for coming to this region (Figure 2). Most of the interviewees named more than one argument for their visit. The most frequently mentioned were observing nature, fresh air and enjoying the quiet. In a second step, people were also asked if they intended to look out for specific plants or observe specific animals. This answer was ticked by $27.6 \%$ of the interviewees. $19.6 \%$ could name the animal or plant species that they wanted to observe. The marmot (Marmota marmota) was the most frequently mentioned, followed by Gentiana species and chamois (Rupicapra rupicapra). Few significant differences were detected: while certain features of the natural landscape, such as peaks and lake, were ranked significantly higher by people with a higher educational 


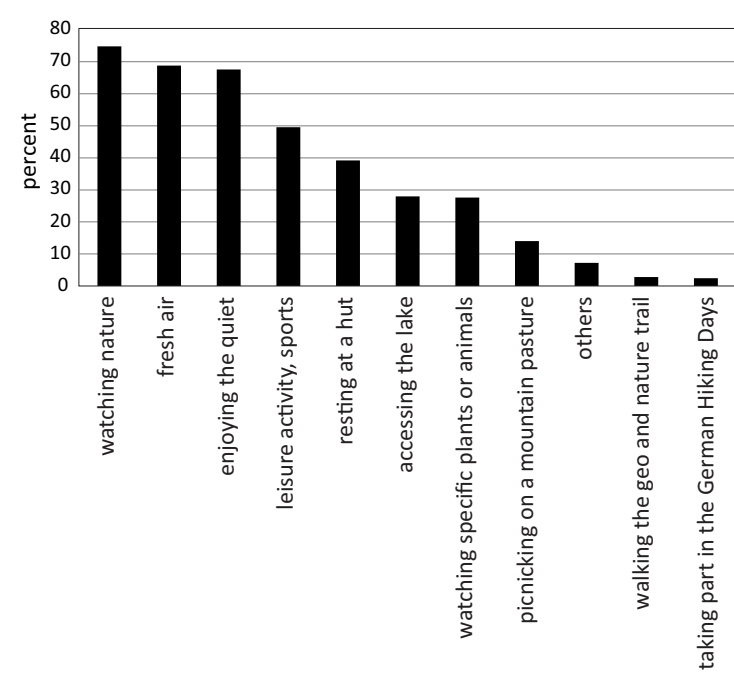

Figure 3 - Motives for hiking in the study area given by the interviewees in the Allgäuer Hochalpen; 249 interviewees, multiple answers possible.

background, elements related to Alpine farming did not differ significantly between groups.

The interviewees were asked to evaluate the landscape with pairwise opposing terms (see Figure 4). It was perceived as natural, colourful, diverse and as expected. People visiting the region for the first time rated diversity and colour significantly lower than the other groups.

Also a list of given landscape elements had to be evaluated. On a scale of 2 (like) to -2 (dislike) (Figure 5), the most preferred elements were: 1 : the pano-

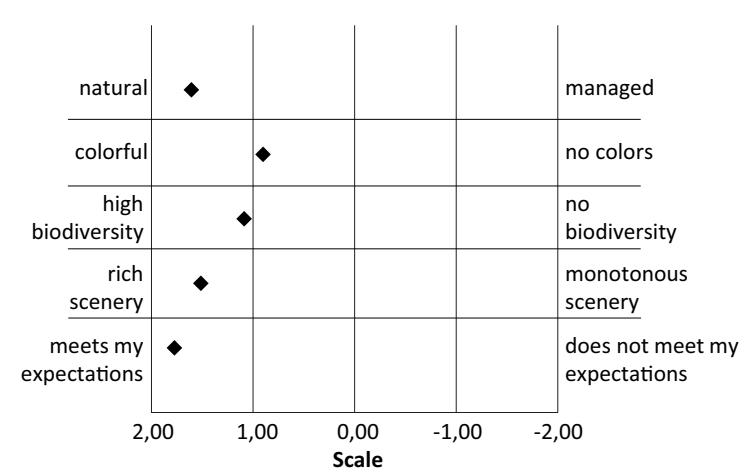

Figure 4 - Average landscape evaluation with given pairwise opposing terms, 249 interviewees, five step scale from +2 strongly agree with term on the left to -2 strongly disagree with term on the left and therefore fully agree with term on the right.

ramic view (described as elements you can see in the distance), 2: the lake, 3: mountain peaks, 4: torrents, and 5: Alpine meadows. Least liked were the green alder shrubs (Alnus viridis) and the scree slopes. Signs of Alpine farming, such as visibility of cattle and huts, were ranked in between. Livestock trails / terraces, resting places for cattle and cattle watering tanks were less liked. Many interviewees ticked don't know or left the field blank for resting places of livestock (20\% of the interviewees), springs, deer (16.8\% each), water supplies $(14.8 \%)$ and livestock trails and terraces $(10.8 \%)$.

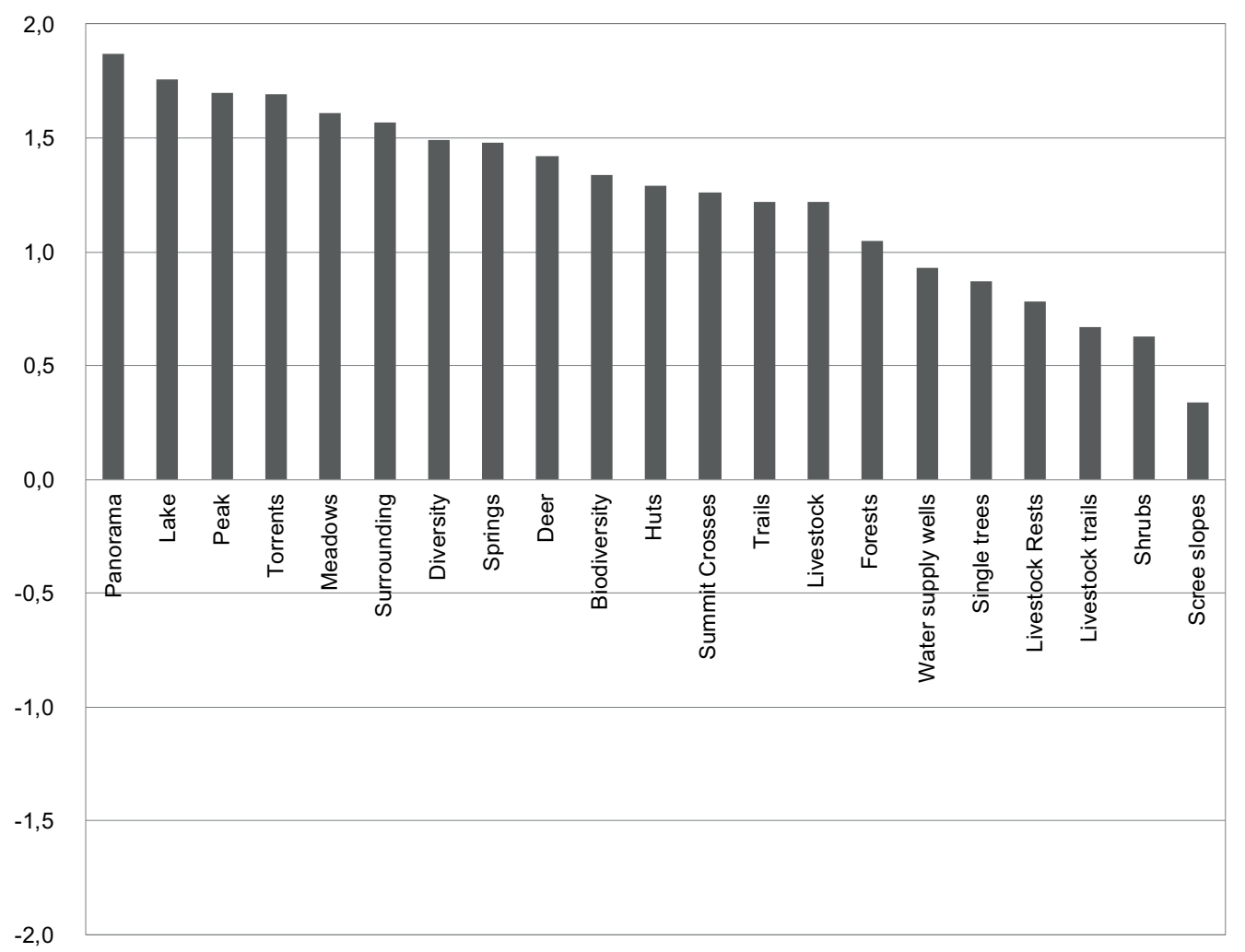

Figure 5 - Ranking of different landscape elements, +2 like it, 0 neither / nor, -2 dislike, 249 interviewees. 


\section{Discussion}

Trail use

Our study lacks a long-term systematic observation of visitors to the study area (e.g. Rupf \& Siegrist 2013), and a study design covering the whole summer. In the interviews it could be shown that people are aware of being in a protected area. Only very few hikers used the informal trails in the study area. The main motivation for using informal trails was to reach a mountain peak or to hike around the entire lake. Informal trail use in the study area, therefore, does not originate from visitors taking shortcuts, described by Cole et al. (1987) as being one of the main reasons, or static activities such as picnicking, photography and observation of wildlife, as well as observing climbers (described for the Yellowstone National Park by Walden-Schreiner \& Leung 2013). Some of the offtrack activities at Schochen and Seekopf found in our study might be explained by efforts to avoid crowding (Manning 1999) because of high visitor numbers on the nearby Nebelhorn peak, which is accessible by cable car. Our findings are also in line with observations in Belgium where people were found to go off-track with the aim of accessing attractive scenic sites (Dumont et al. 2005).

Internet picture assessment and interview results

Both the results from the photo analysis and the results of the survey show that elements dependent on mountain farming activities were most frequently photographed or are perceived as being the most beautiful. However, they were not associated with farming activities. Interestingly, direct evidence of mountain farming activities and grazing animals were rarely photographed. Other studies using user-based photographs also indicate high preferences for traditional farming landscapes (e.g. Hawley et al. 2012).

Across all respondent groups, the same landscape elements, such as panoramic view and lake, were preferred. A high appreciation of Alpine cultural landscapes with few traces of human presence has been reported in several studies (e.g. Henniker 1995; Hecht et al. 2005; Henniker et al. 2008). This correlates with other perceptions in other landscapes within the Alpine arc and serves as a pan-Alpine stereotype or cliché image (Dillinger 2000; Schmidt 2011). The high valuation of the lake is in line with other landscape preference studies e. g. Lupp \& Konold (2008) or Bauer et al. (2009), while scrubland is disliked. Interviewees, however, mainly perceived grasslands as a natural landscape, even though it depends on regular management. This demand for natural Alpine landscapes acts as a contrast to everyday life and therefore should be free of disturbing elements needed to maintain these landscapes, such as huts or infrastructure connected with mountain farming (Burckhardt 2010). Considering the statements by visitors indicating high appreciation of diverse species-rich Alpine agricultural land (Linde- mann et al. 2010), in this study the highest preferences were expressed for panoramic views, the lakes and alpine meadows as a whole. This preference supports the view that an appreciation of biodiversity is based mainly on a scenic landscape level, on land-use patterns and on just a few flagship species (Lupp et al. 2013).

\section{Conclusions}

Considering trail use in the study area, the main impact seems to derive from the use by livestock. It is more a question of balancing grazing to maintain the open Alpine landscape to provide scenic views, and of not allowing too much grazing to cause vegetation damage and biodiversity losses. It could be shown that almost half of the interviewees only walked a $15 \mathrm{~min}$ trail and that frequentation of the trail dropped to only a few hikers per day walking beyond a one-hour hiking distance. Only very few people had used informal trails in the study area during the interview period. However, regulation of informal trail use will be difficult, since mountaineers want to reach the Schochen peak to enjoy a scenic view away from the crowds or to hike around the entire lake. Moreover, it will be difficult to prevent people from doing this if they so wish, especially considering that a large number of interviewees were already familiar with the study area and its nature conservation value. If the use of informal trails is considered intolerable, fencing off these trails will not be a solution and may even be extremely difficult to implement, especially when livestock is supposed to move around freely to maintain the open character of the landscape and the biodiversity. Providing formal trails might be an alternative. However, especially for the lake, a formal trail would draw much attention (as it will be within a one-hour range from the cable car) and might even encourage many of the hikers heading for the hut to take the trail around the lake, too. This would lead to more disturbance and habitat fragmentation in this extremely sensitive alpine area which hosts a number of sensitive species like the grouse.

The high appeal of the scenic qualities is based on a perceived high naturalness. While most of the visitors are aware that they are in a protected area, even frequent visitors to the study area are only partially aware that it needs regular management and the related infrastructure for animal husbandry. One solution might be that infrastructure needed for mountain farming could be better designed and integrated into the scenery in order to reduce its visual impact. In addition, more information and raising awareness for mountain farming seem to be necessary and could be a more important part of the communication work of the Natura 2000 site manager. The relevant authorities might also work on the acceptance issue or help farmers to improve the overall scenic appearance of the infrastructure. Not only for the Natura 2000 site managers, but also for the responsible authorities, focusing on raising awareness and acceptance of management 
and mountain farming in the general public is essential and worth pursuing. Besides local nature conservation agencies, this would involve the local Departments for Food, Agriculture and Forestry with their knowledge, education and consultation programmes for farmers and landowners as well as tourism agencies or organizations such as the German Alpine Club working together to convey the importance of mountain farming.

\section{Acknowledgments}

The authors would like to thank the farmers, the Natura 2000 site manager Henning Werth and the interviewees for participating in the surveys. The study and work for this paper was conducted within the projects BiKliTour and Urban Forests 2050. The BiKliTour project was supported by the Federal Agency for Nature Conservation and funded by the Federal Ministry for the Environment (Funding Number FKZ 351087 0100). The Urban Forest 2050 project was sponsored by the Bavarian State Ministry for Food, Agriculture and Forestry (FKZ G 36). We also thank Elisabeth Hamzi-Schmidt for polishing the language.

\section{References}

Antrop, M. 2004. Landscape change and the urbanization process in Europe. Landscape and Urban Planning 67: 9-26.

Atteslander, P. 2003. Methoden der empirischen Sozialforschung. Berlin and New York.

Bätzing, W. 2002. Die Alpen. Geschichte und Zukunft einer europäischen Kulturlandschaft. München.

Bauer, N., A. Wallner \& M. Hunziker 2009. The change of European landscapes: Human-nature relationships, public attitudes towards rewilding, and the implications for landscape management. Journal of Environmental Management 90: 2910-2920.

Burckhardt, L. 2010: Warum ist Landschaft schön? Die Spaziergangwissenschaft. Berlin.

Bortz, J. \& N. Döring 2003. Forschungsmethoden und Evaluation. Heidelberg.

Cole, D.N., M.E. Petersen \& R.C. Lucas 1987. Managing wilderness recreation use. United States Department of Agriculture, Forest Service. General Technical Report INT-230. Ogden, UT.

Cresswell, A. 2003. Research Design. Qualitative, Quantitative and Mixed Methods Approaches. Second Edition. Thousand Oaks.

Deneke, D. 1969. Methodische Untersuchungen zur historisch-geographischen Wegeforschung im Raum zwischen Solling und Har\%: Göttingen.

Destatis 2013a. Bildungsstand. Available at: https://www.destatis.de/DE/ZahlenFakten/ GesellschaftStaat/BildungForschungKultur/ Bildungsstand/Tabellen/Bildungsabschluss.html (accessed 18/02/2014)

Destatis 2013b. Bevölkerung nach Altersgruppen. Available at: https://www.destatis.de/DE/
ZahlenFakten/GesellschaftStaat/Bevoelkerung/ Bevoelkerungsstand/Tabellen_/lrbev01.html (accessed 18/02/2014)

Dirlinger, H. 2000. Bergbilder: Die Wahrnehmung alpiner Wildnis am Beispiel der englischen Gesellschaft 17001850. Frankfurt, Berlin, Bern and Wien.

Dumont, B., P. Roovers \& H. Gulinck 2005. Estimation of off-track visits in a nature reserve: a case study in central Belgium. Landscape and Urban Planning 71: 311-321.

Garz, D. \& K. Kraimer (eds.) 1991. Qualitativ-empirische Sozialforschung - Konzepte, Methoden, Analysen. Opladen.

Gobster, P.H., J.I. Nassauer, T.C. Daniel \& G. Fry 2007. The shared landscape: what does aesthetics have to do with ecology? Landscape Ecology 22: 959-973.

Großmann, Y. 2007. Typisierung landschaftsbezogener alpiner Erholungsnutzer im Sommerhalbjahr. Eine Analyse im Gebiet „Steinernes Meer“ in der Großschutzgebietsregion Nationalpark Berchtesgaden. In: Henning, S., Y. Großmann \& J. Pfeiffer, Ergebnisse aus dem InterReg III a-Projekt. EURegionales Erbolungsgebiet Nationalpark Berchtesgaden / Salzburger Kalkhochalpen. Ramsau.

Heuchele, L., C. Renner, R.U. Syrbe, G. Lupp \& W. Konold 2014. Nachhaltige Entwicklung von Tourismusregionen im Kontext von Klimawandel und biologischer Vielfalt. Culterra 64, Schriftenreihe der Professur für Landespflege der Albert-Ludwigs-Universität Freiburg.

Höchtl, F., S. Lehringer \& W. Konold 2005. "Wilderness": what it means when it becomes a reality - a case study from the southwestern Alps. Landscape and Urban Planning 70: 85-95.

Hunziker, M. 1995. The spontaneous reafforestation in abandoned agricultural lands: perception and aesthetical assessment by locals and tourists. Landscape and Urban Planning 31: 399-410.

Hunziker, M., P. Felber, K. Gehring, M. Buchecker, N. Bauer \& F. Kienast 2008. Evaluation of landscape change by different social groups. Mountain Research and Development 28: 140-147.

Howley, P., C.O. Donoghue \& S. Hynes 2012. Exploring public preferences for traditional farming landscapes. Landscape and Urban Planning 104: 66-74.

Kampmann, D., F. Herzog, P. Jeanneret, W. Konold, M. Peter, T. Walter, O. Wildi \& A. Luscher 2008. Mountain grassland biodiversity: impact of site conditions versus management type. Journal for Nature Conservation 17: 12-25.

Konold, W. 1996. Von der Dynamik einer Kulturlandschaft. Das Allgäu als Beispiel. In: Konold, W. (ed.): Naturlandschaft - Kulturlandschaft. Die Veränderung der Landschaften nach der Nutz̧barmachung durch den Menschen: 121-136. Landsberg.

Krauss, H. \& G. Schlapp 2013. Gebietsbetreuerinnen und Gebietsbetreuer in Bayern. Natur und Landschaft 6: 242-250. 
Kromrey, H. 2009. Empirische Sozialforschung. Stuttgart.

Liddle, M. 1997. Recreation Ecology. The ecological impact of outdoor recreation and tourism. London.

Lindemann-Matthies, P., R. Briegel, B. Schüpbach, \& X. Junge 2010. Aesthetic preference for a Swiss alpine landscape: The impact of different agricultural land-use with different biodiversity. Landscape and Urban Planning 98: 99-109.

Lupp, G., L. Heuchele, C. Renner, P. Pauli, W. Konold \& D. Siegrist 2013. Biologische Vielfalt und Klimawandel als Herausforderung für naturräumlich besonders wertvolle Tourismusdestinationen - Wahrnehmung und Handlungsbedarf der Akteure in ausgewählten Beispielregionen Deutschlands, Naturschutz. und Landschaftsplanung 45(3): 69-75.

Lupp, G. \& W. Konold 2008. Landscape preferences and perception of both residents and tourists: A case study in the Müritz National Park (Germany). In: Siegrist, D., C. Clivaz, M. Hunziker \& S. Iten (eds.), Visitor Management in Nature-based Tourism - Strategies and Success Factors for Parks and Recreational Areas, Series of the Institute for Landscape and Open Space: 47-58. Rapperswil.

Macnamara, J. 2005. Media content analysis: Its uses, benefits and Best Practice\#Methodology. Asia Pacific Public Relations Journal 6(1): 1-34.

Manning, R.E. 1999. Studies in Outdoor Recreation. Second Edition. Corvalis.

Orsi, F. \& D. Geneletti 2013. Using geotagged photographs and GIS analysis to estimate visitor flows in natural areas. Journal for Nature Conservation 21: 359-368

Qiu, L., S. Lindberg \& A.B. Nielsen 2013. Is biodiversity attractive? - On-site perception of recreational and biodiversity values in urban green space. Landscape and Urban Planning 119: 136-146.

Pröbstl, U. 2010. Natura 2000, Sport und Tourismus in Europa. Herausforderungen, Optimierungspotenziale und beispielhafte Lösungen. Natur und Landschaft 85(9/10): 402-407.

Rochefort, R.M. \& S.T. Gibbons 1993. Impact monitoring and restoration in Mount Rainier NP. Park Science 13: 29-30.

Rochefort, R.M. \& D.D. Swinney 2000. Human impact surveys in Mount Rainier National Park: past, present, and future. In: Cole, D.N., S.F. McCool, W.T. Borrie \& J. O'Loughlin (eds.), Wilderness science in a time of change conference, Wilderness ecosystems, threats, and management. Proceedings RMRS-P-15-VOL-5, Ogden: 165-171.

Rupf, R. \& D. Siegrist (eds.) 2013. VISIMAN Beiträge zu Besuchermonitoring und Besuchermanagement in Pärken und naturnaben Erholungsgebieten, Rapperswil.

Schmidt, A. 2011. Die Alpen. Eine Schweizer Mentalitätsgeschichte. Zürich.

Schulze, G. 1997. Die Erlebnisgesellschaft: Kultursoziologie der Gegenwart. Frankfurt, New York.

Tyrväinen, L., M. Uusitalo, H. Silvennoinen \& E. Hasu 2014. Towards sustainable growth in nature- based tourism destinations: Clients' views of land use options in Finnish Lapland. Landscape and Urban Planning 122: 1-15.

Walden-Schreiner, C. \& Y.F. Leung 2013. Spatially Characterizing Visitor Use and Its Association with Informal Trails in Yosemite Valley Meadows. Environmental Management 52: 163-178.

WWF 2004. Die Alpen: das einzigartige Naturerbe Eine gemeinsame Vision für die Erhaltung ibrer biologischen Vielfalt.

Zimmermann, P., E. Tasser, G. Leitinger \& U. Tappeiner 2010. Effects of land-use and land-cover pattern on landscape-scale biodiversity in the European Alps. Agriculture, Ecosystems \& Environment 139(1-2): 13-22.

\section{Authors}

\section{Gerd Lupp}

holds a PhD in Forestry and is a research associate at the Chair for Strategic Landscape Planning and Management, TU München. His research interests range from landscape perception and nature-based tourism to ecosystem services, forest development and renewable bioenergy production. Chair for Strategic Landscape Planning and Management, TU München, Emil-Ramann-Str. 5, 85354 Freising, Germany. Email: gerd.lupp@tum.de; luppg@gmx.de

\section{Markus Feuerstein}

MSc, studied forest sciences at Freiburg University and is currently a trainee at the Forest Authority in Bavaria. Heinzenstr. 24, 66440 Blieskastel, Germany. E-Mail: Markus.Feuerstein@gmx.de

\section{Linda Heuchele}

MSc, studied forestry sciences with a focus on nature conservation and landscape management at the University of Freiburg. From 2011 to 2014 she worked at the Chair for Landscape Management Freiburg on the development of adaptation strategies in the field of climate change, biodiversity and tourism. E-Mail: lpflege@landespflege.uni-freiburg.de

\section{Werner Konold}

agricultural engineer, holds the Chair for Landscape Management in the Faculty of Environment and Natural Resources of Freiburg University. His research interests are the history and ecology of cultural landscapes and the driving forces behind them, as well as nature conservation in a broad sense, new land-use systems and adaptation to climate change. University of Freiburg, Chair for Landscape Management, Institute of Earth and Environmental Sciences, 79085 Freiburg, Germany. E-Mail: werner.konold@landespflege.uni-freiburg.de 